The man who never was? The Italian transition and 2008 election

\title{
JAMES L. NEWELL
}

European Studies Research Institute

University of Salford

Salford M5 4WT

j.1.newell@salford.ac.uk

Paper prepared for presentation to the panel, 'Italian Politics after the 2008 Election: Another Turning Point?', 59 $9^{\text {th }}$ Annual Conference of the UK Political Studies Association, Manchester, 7 - 9 April 2009. 


\title{
The man who never was? The Italian transition and 2008 election
}

\begin{abstract}
The implications for the co-called Italian transition of the 2008 election initially seemed significant - but have since became increasingly uncertain as Berlusconi's conflict of interests has risen higher up the political agenda. This underscores the pertinence of asking about the sense in which the notion of 'transition' is actually applicable to the Italian case at all - bearing in mind that it describes a process now supposedly underway for some seventeen years; and bearing in mind that its end point can seemingly not be identified (though by definition 'transition' implies movement between two points). Discovering if the term applies to the Italian case and if so whether 2008 has brought its conclusion nearer requires exploring if the political protagonists that have emerged from the election as the most significant players - the Partito della Libertà and the Partito Democratico - have sufficient commonality of view, sufficient desire and sufficient power to complete a process of constitutional overhaul. The evidence suggests that while they have the view and the desire, there are significant limitations on their power. The election might potentially have been a watershed in the so-called Italian transition in the broader sense of system performance, aside from formal constitutional change. Here too, however, the evidence points away from the idea that 2008 represents a real sea change though the chances seem good that it will come to be perceived as such.
\end{abstract}

\section{Introduction}

What are the implications for the Italian transition of the general election of 2008? In the immediate aftermath of the campaign, it looked for a while as though the implications might be quite significant: the election had brought to office a government consisting of just two parties, and with a large majority - one that, from the point of view of its own power, was born in the most favourable circumstances a new government has ever enjoyed in the history of the Italian republic (Chiaramonte, 2009). Fragmentation among the parties of opposition had likewise declined dramatically and by far the largest of these, the Partito Democratico (Democratic Party, PD), had made conspicuous efforts to conduct a campaign that abandoned the demonising, anti-Berlusconi rhetoric of the past: wanting to convey an image of novelty for his party and to encourage 'prospective' voting, Walter Veltroni sought to avoid references to Silvio Berlusconi's conflict of interests and past performance, as a focus on the past would inevitably have revived memories of the Prodi government - which was the last thing he wanted to do (Favretto, 2009). The situation in the election's immediate aftermath, then, was one in which the main parties of government and opposition shared over 70 per cent of the vote and 78 per 
cent of the seats between them, ${ }^{1}$ and had apparently abandoned a style of competition reciprocal denials of the claims of the other to legitimacy - which, especially because it tended to be self-reinforcing, had hitherto contributed significantly to rendering institutional reform intractable.

It was therefore not altogether surprising that in May, Prime Minister and leader of the opposition seemed intent on a regular set of meetings with a view to finding mutually acceptable institutional reforms - even less surprising given the clear incentives both men had: successful reform arguably offered the opportunity of a place in Italian political history as the fathers of a new constitutional settlement, something that seemed likely to be especially attractive to the aging Berlusconi, reputed to want to crown his career at the end of his term as Prime Minister with election to the Presidency.

On the other hand, as Pasquino (2009: 240-1) has pointed out, 'the thaw between the leaders of the two major parties lasted l'espace d'un matin', Veltroni having underestimated the extent to which the decisions Berlusconi would have to take as Prime Minister would be affected by his unsolved conflict of interests - and, in fact, two of the Government's earliest decisions (concerning rejection of the European Court's decision that his Rete 4 Channel be shifted to satellite broadcasting, and an amendment that postpones one of his corruption trials ${ }^{2}$ ) sent this conflict right to the top of the political agenda. These circumstances revealed that there were inherent tensions between dialogue on constitutional reform, and the requirements of effective opposition. On the one hand, the notably restrained nature of Veltroni's response to the Government's proposals was insufficient to prevent Berlusconi, in July, casting doubt on the prospects for dialogue and accusing the PD "of having brought into Parliament extremist and punitive fringes" (Montanari, 2008). On the other hand, the PD leader's attempts to keep hopes of dialogue alive were unable to satisfy radical critics who argued that the effect would be to prevent the opposition from keeping the Government accountable - as earlier attempts at cooperation had suggested would happen. ${ }^{3}$ Moreover, the attempts risked weakening the PD, as polls suggested. Thus, if in June 51 percent of those who had voted for the centre left in April judged the opposition to be conducting itself in a 'balanced' way, 41 percent felt that it was 'too docile' (Mannheimer, 2008).

So the likely impact on the transition of the election outcome soon became unclear. Yet it is worth asking ourselves what, almost one year on from the elections, the

\footnotetext{
${ }^{1}$ Proportions higher than ever previously achieved since the war and well in line with the corresponding proportions for the other large European democracies.

${ }^{2}$ This was to be achieved by means of legislation providing for the discretionary postponement of trials where charges did not involve issues of public safety - supposedly to help increase the rate of throughput of the judicial system as a whole.

${ }^{3}$ At the time of the Bicameral Commission for Constitutional Reform in 1997, for example, when it had sought the entrepreneur's cooperation by refraining from legislation to deal with his conflict of interests, the centre left found that in the end, Berlusconi withdrew cooperation anyway leaving constitutional reform in tatters but his media empire intact.
} 
current state of play is with regard to the Italian transition - simply because the concept has been so central to academic analyses of political changes since the early 1990s. This means that asking the question can help us clarify a number of issues relevant to understanding the current trajectory of change in Italian politics in general. With this in mind, the remainder of the paper is structured as follows. First, we consider the notion of 'transition' itself in order to establish the nature of the concept's relevance to the Italian case. In the section following we explore what the effects of the election outcome have been in terms of the emergence of a unity of intents on constitutional change among significant actors, and the chances of it being achieved in the current legislature. In the fourth section, we consider whether the 2008 election outcome constitutes a watershed in the transition in the broader sense of system performance, aside from formal constitutional change. The final section concludes.

\section{The notion of 'transition'}

As is well known, the concept of 'transition' refers to a state of 'movement' from one regime to another, where the term 'regime' means that complex of rules, norms and procedures which govern: recruitment to positions of political authority (e.g. as a consequence of the electoral system); the functioning of political institutions (e.g. Parliament); the definition of the political community itself (Pasquino, 2000: 202). Equally well known are the changes in Italian politics that are thought to give the term its relevance. In essence, the collapse of the Berlin Wall in 1989; the organisational disintegration of the then governing parties under the weight of a massive corruption scandal, and electoral-system change in 1993 had all brought a party-system transformation away from the traditional 'polarised pluralist' (Sartori, 1976) pattern in the direction of fragmented bipolarism. On the one hand, then, party-system transformation seemed to have led the political system as a whole to acquire more of the features than it allegedly had of a 'normal majoritarian democracy': electoral coalitions enabled voters collectively to decide on the party composition of governments, directly; alternation in office between competing coalitions was possible; governments, through greater recourse to legislative decrees, had a stronger role in Parliament (Capano and Giuliani, 2001, 2003; Newell, 2006; Vassallo, 2007). On the other hand, the two coalitions which, by the first election of the new millennium had emerged as apparently permanent features of the political landscape were fluid and unstable. On the centre right, the Casa delle libertà seemed able to remain united only as long as its leader remained sufficiently popular as to give it a reasonable prospect of beating the centre left; while on the centre left, cohesion was undermined by the absence of any kind of coalition maker. ${ }^{4}$ So, while the average life of governments during the First Republic was somewhat less than a year (322 days), in the period from the 1994 election to the election of 2001 it was just over a year (422 days). Thus it was, that, in addition to the electoral reform of 1993, more thoroughgoing institutional reform was thought to be necessary in order to consolidate the changes that had been achieved thus far and to overcome the continuing

\footnotetext{
${ }^{4}$ That is, a party which, because of its relative size, is able to dictate the terms on which coalition formation will take place and, thus, to impose a minimum of discipline on allies.
} 
weaknesses in the political system's mode of functioning, in particular, the cohesion of governing majorities and thus their capacity for efficient and effective policy making.

But the conditions that underpinned convictions of the necessity for further institutional change were precisely those that made it difficult, if not impossible, to achieve that change. Already with the failure of the Bi-cameral Commission for Constitutional Reform under Massimo D'Alema in 1997, it was clear that party-system fragmentation had turned large numbers of parties into partisan veto players (Tsebeliss, 2002) all wanting change, but changes going in contrasting directions so that a majority in favour of any given set of changes became impossible to construct.

If this served to sustain the view that the Italian political system was somehow caught in mezzo al guado, in a 'never ending' transition, as some authors called it, then it also made it legitimate, after a certain point, to ask about the extent to which the term 'transition' was, in fact, any longer applicable. On the one hand, if one looked back to Italy's last regime transition, the one that took place between 25 July 1943 and 1 January 1948 , then one discovered that it was completed in less than five years. If one dates the onset of the current transition from the day, on 17 February 1992, that Mario Chiesa was caught by the Carabinieri flushing his bribes down the toilet, then one is forced to reckon with a 'transition' that has now been going on for over seventeen years! More importantly, if the term 'transition' implies a state of movement between two points, then it could be pointed out that the apparent absence of any political actor or group of actors sufficiently powerful to impose a solution that would end the transition in effect meant that the second of the two points did not exist, or at least could not be identified. And if it could not be identified, in what sense could the system be held to be in movement towards it, that is, 'in transition'?

It is for these reasons that Martin Bull and I (2009) have written that rather than focussing on a supposed transition, it may be rather more fruitful for an understanding of Italian politics to analyse what, in substance, is distinctive about the period since the early 1990s: the manner in which a debate over fundamental institutional (including electoral) reform has become entangled in day-to-day to politics. That is to say, Italian political debate has, at least since the 1980s, been characterised, on the one hand, by a general consensus that fundamental institutional reform is needed, and, on the other, by a lack of agreement over what needs to be changed. 'Furthermore, since the end of the 1990s, there has been deep-seated disagreement over the best (or 'legitimate') method by which such a reform might be achieved - beyond acceptance of the formal procedures for reform laid down by the Constitution. As a consequence of these three factors, the debate over institutional reform has become an intimate part of the substantive struggle for political power' (Bull and Newell, 2009: 43). And paradoxically, the enmeshing of 'institutional' and 'political' struggle made successful completion of any transition process less, rather than more likely - as the events surrounding the passage and the aftermath of the electoral law reform in December 2005, and the referendum on constitutional reform of June 2006, illustrated. 
On the other hand, what seems equally true is that the generality of the changes that have overtaken the Italian system in the last fifteen years are sufficiently profound to sustain a case that in a broader sense, the Italian transition is already complete. In other words, if we detach the term 'transition' from an excessively close connection with formal, constitutional, change, then we may be able to detect a change in the workings of the political system sufficiently thoroughgoing to enable us to argue that, more broadly construed, 'the fundamental rules of the game' have indeed been transformed as compared to what they were before. So, in order to take analysis of the 2008 election and the Italian transition further, we have to do two things. One, taking the conventional understanding of the term, is to explore the extent to which the election outcome has enhanced the prospects for agreement among political actors having the power to engineer fundamental constitutional change capable of lasting: only if there are actors at least potentially capable of engineering lasting constitutional change does the term 'transition', conventionally understood, seem relevant. The other, construing 'transition' more broadly, is to explore what the election and its outcome means and is likely to mean for the performance of actors and the political system, generally speaking.

\section{The prospects for a new constitutional settlement}

Article 138 of the Italian Constitution stipulates that amendments to it require each chamber of Parliament to vote in favour on two occasions separated by an interval of not less than three months; that those in favour must on the second occasion be a majority of the chambers' members (not just of those voting); that citizens may subject the amendments to a referendum where, on the second occasion, they have been passed with the support of less than two thirds of the members of one or both chambers. This means that if a new constitutional settlement is to come in the present legislature, then it will have to be legislated for by the PD and the Popolo della Libertà (People of Freedom, PdL) working together. No other combination - see Table 1 - provides the two thirds required to avoid the risk of a repeat of the 2006 experience (Bull, 2007) when constitutional reform passed in opposition to the centre left provoked a referendum, which the centre right lost by a margin of almost two to one. However, if these two actors are successfully to conclude a reform, then they must (1) have a sufficient degree of commonality of outlook to enable them to do so; (2) sufficient desire to do so; (3) sufficient power to do so.

The most obvious place to begin in considering the first of these three issues is the two main coalitions' electoral programmes. These, however, are unhelpful: the PD's programme listed twelve areas of government action, one of which - the eleventh; 'Governing democracy' - outlined a set of proposals for constitutional overhaul; but the issue was not addressed by the 'Seven missions for the future of Italy' of the PdL's programme: perhaps an instance, rare in the 2008 campaign, of competition through 'issue ownership' rather than through debate over common issues (Budge and Farlie, 1983; Budge et al. 1987). True, the programmes did show a degree of overlap in terms of issues closely bound up with constitutional overhaul, notably, fiscal federalism, where the programmes converged 'in envisaging a high level of local financial autonomy coupled 
with the decentralisation of service provision' (Capriati, 2009). Given the electoral success of the Northern League (NL), the theme is likely to be an important one in the current legislature.

Somewhat more helpful are the volumes based on the leaders' speeches, which set out their broader political visions: La Nuova Stagione (2007) for Walter Veltroni and L'Italia che ho in mente (2000) for Berlusconi. The overlaps are evident. Veltroni's book lists proposals a number of which were directly reflected in the PD's programme (which is, perhaps, revealing of the much more centralised way in which the programme was drafted as compared to 2006 (Campus, 2008)): a single legislative chamber chosen using the two-ballot system, together with: a Senate representative of the sub-national tiers of government, an executive requiring the confidence of the Chamber only, and a Prime Minister with the power to request the President to revoke the appointment of individual ministers. Berlusconi's book indicates (p. 59) support for the two-ballot system linking it, as does Veltroni, by implication, to the consolidation of bipolarism and alternation between compact governing and opposition line-ups. It also echoes (p. 61) Veltroni's position concerning the relative roles and powers of the Chamber of Deputies and the Senate. Finally, Berlusconi's echoes Veltroni's book in looking for a reinforcement of the position of the Prime Minister, even though it goes beyond Veltroni in seeking to give the head of the executive 'a direct popular mandate' (p. 300) - a position which, as Pasquino (2009: 234) points out, has hitherto been resisted by narrow margins in debates on constitutional reform by those who argue that it would 'risk transforming parliamentary and political crises into institutional crises'. In short, there appears, in broad outline, to be enough in common between the PD and the PdL to tip the balance of probability - at least on this ground - in favour of there being a new constitutional settlement some time during the course of the current legislature.

But - to come to the second issue - to what degree are the main protagonists likely to feel driven to prioritise such a settlement? Of the position of the PD, there appeared little doubt when Veltroni was leader, since perceptions of the need for a revolution in the mode of functioning of the party and political systems lay at the very heart of what drove the emergence of the party, and its leader's decision to run alone in 2008, in the first place. As Veltroni (2007: 20) put it in the book cited above: 'the Democratic Party was born in order to move beyond the idea that what counts is to win elections, that is, to beat the opposing line-up by fielding the broadest coalition possible regardless of its actual capacity to govern the country'. On the other side, it is said that Berlusconi is, on a personal level, rather indifferent to institutional questions - an attitude that would seem to chime rather closely with his populist style of politics bearing in mind that one of the hallmarks of populism is precisely an intolerance of institutional and procedural restrictions on the use of power by the popularly chosen leader (who is, after all, perceived as being both of the people and uniquely qualified to lead the people). But what appears at least equally true is that the need for constitutional overhaul is now an unquestioned and taken-for-granted matter of consensus right across the political spectrum at the elite level - and ultimately it may be this - the fact that politicians themselves see things that way - that makes it meaningful to continue to apply to the Italian case the term 'transition', a term routinely used by politicians, as suggested by 
Veltroni's book with its frequent references to 'a long and so-far incomplete transition' (p.7). So, when the PdL's 'Carta dei Valori' 5 states that the process of constitutional reform will be restarted in the present legislature 'with the common commitment to complete it', we have to take this as evidence that the centre right too is committed to prioritising a new constitutional settlement.

What, then - to address the third issue - of the power of the political protagonists actually to realise such a settlement? Here, much will depend on the capacity of the two principal line-ups to retain sufficient unity on substantive issues to enable them to negotiate compactly on constitutional issues. On the centre right, areas such as taxation and fiscal federalism may provide major tests since they are likely to have a significant impact on the Government's ability to deal with the economic crisis, while also being central to the appeal of the NL which is numerically indispensible to the Government's survival. The problem is that the NL's proposals clash with the electoral requirements of other parts of the coalition for retention of a significant element of fiscal solidarity between richer and poorer regions, and the potential for tension on the issue is surely greater now that the merger between FI and AN has become definitive (meaning that FI no longer has the freedom to mediate between AN and the NL).

A second potentially significant source of tension between the NL and the PdL is the electoral-law referendum, which seems likely to go ahead in June, and the attitude the PdL takes towards it. The referendum was originally brought onto the agenda of Italian politics in 2007 by 'CO.R.EL 2008', a cross-party grouping of intellectuals and persons in public life that managed to gather the required number of signatures to make possible the holding of a referendum on three proposals to abolish parts of the electoral law. Of the three, the two most important proposals would remove the current option available to parties to field lists as part of a coalition with other parties, and would strike down those clauses allowing attribution of the majority premium to the largest coalition. The result would thus be to reserve the premium to the largest single list, and automatically to raise the vote thresholds for all lists to 4 per cent in the Chamber and 8 per cent in the Senate. ${ }^{6}$ If passed, the proposals would considerably benefit the PdL while being highly damaging to the NL.

On the other hand, the League's knowledge that it has been the clear winner in terms of the share-out of government positions - having, in the aftermath of 2008 , obtained four of the 21 ministers: a share much larger than its share of the vote - works in the direction of its continuing loyalty. It also obtained portfolios (Home Affairs; Agriculture Food and Forests; Legislative Simplification; Federal Reform) closely

\footnotetext{
${ }^{5}$ This was published alongside the PdL's programme for the 2008 election and is available at http://www .forzaitalia.it/speciali/carta_valori_pdl.pdf

${ }^{6}$ The third proposal would have the effect of abolishing the possibility of fielding the same candidate in more than one constituency, an option that, by allowing party notables to head the lists in multiple constituencies, gives them, so the argument goes, unwarranted powers of patronage. This is because, by simply opting for one of the many seats they are able to win, they have it within their power to secure the election of the best placed of the non-elected candidates in all of the other constituencies in question.
} 
reflecting the issues on which it has sought to construct its distinctive profile (Pasquino, 2009). This means that in any situation of tension with its ally, the calculation of whether, in terms of its support, it does better by breaking, or by staying on to exploit the potential of its offices is a much more difficult one to make than it would have been had its offices more closely reflected its share of the vote. Moreover, as long as any package of proposed constitutional and institutional reforms includes 'federalism', the NL may not care very much about many of the remaining matters. If, for example, the two largest parties were to agree on a reform of the electoral law based on the two-ballot system with single member constituencies as the PD's programme proposed, then it could have little to object to given the geographical concentration of its vote.

A second arena of potential disunity lies within the PdL itself. On the one hand, already on day two of the PdL's founding conference at the end of March 2009, the divisions between the perspectives of former-AN leader, Gianfranco Fini,, and the antiimmigrant populism and 'welfare chauvinism' of those closer to the NL, were evident. This seemed to give some credence to those who had suggested that the process of merging the PdL's constituent parties might prove difficult: just a couple of months before the conference, Giuliano Urbani (2009) had perspicaciously pointed out that the example offered by the creation of the PD was not encouraging - while the weakness of the opposition risked contaminating the coalition of government by suggesting that compactness was no longer a must but an option. As always in politics, predictions made by such high-profile spokespersons, precisely because of their high profile, ran the risk of being self-fulfilling.

On the centre left, the possibilities of productive dialogue with the majority are severely limited by the profound divisions in this area of the political spectrum. In the first place there are the tensions between the PD and Italia dei Valori (Italy of Values, $\mathrm{IdV}$ ). On the one hand, IdV has an interest in acting as a thorn in the side of its larger ally, outflanking the PD by seeking to consolidate an image as a far more consistent and aggressive, that is, resolute, opponent of the incumbent government and prime minister. The reason is that IdV and the PD clearly fish in the same pool of potential voters and the colourful, 'anti-Berlusconi' style of opposition - that is, questioning the legitimacy of the entrepreneur's incumbency - abandoned by the PD during the 2008 campaign, has given IdV an effective means of growing in strength at the expense of the PD: The latter attracts larger numbers of votes than it does of people who, when asked, say they feel close to it (Diamanti, 2008); already in June of last year, while suggesting that the gap separating the centre left as a whole from Berlusconi was essentially stable, polls pointed to a significant shift within the coalition, with di Pietro's party support standing at above 7 percent (Biorcio and Bordignon, 2008: 7). On the other hand, if the PD is to make any electoral headway whatsoever, then besides speaking successfully to radical spirits, it needs also to appeal to moderate elements located towards the centre of the political spectrum. Di Pietro's strident anti-Berlusconi rhetoric is perceived as cutting directly across this; for it makes virtually impossible any dialogue with the UDC, whose leader, Pierferdinando Casini has been explicit in saying that the PD will have to dissociate itself from Di Pietro failing which 'no strategic alliance' with his party will be possible (Di Caro, 2008: 5). 
These tensions act as a brake on dialogue on constitutional reform between the PD and its governing counterpart because, as the period since the election has shown, when the two parties come together, suspicions are automatically aroused that the PD's leaders are too much in 'cahoots' with Berlusconi. This makes it very difficult for them to resist the image painted by Paolo Flores d'Arcais (when he wrote (2008: 4) that the PD was 'by now... an integral component of the partitocratic guild') or by Ricolfi (when he wrote (2008: 54-6) that the PD was seriously out of touch with popular aspirations) leaving the party vulnerable to the attacks of di Pietro and his accusations of excessive timidity. The attacks and accusations then undermine the prospects for dialogue between the two largest parties, the PD and the PdL, still further; for they create for the majority an opportunity too good to be missed: by allowing its spokespersons to dub the opposition as a home to intolerance and therefore as unfit to govern; and by allowing them to embarrass the PD by demanding that it repudiates its ally every time Di Pietro makes one of his more colourful outbursts, the attacks and accusations enable them to drive, between the opposition parties, a wedge still deeper than the one that had existed hitherto. And by raising still further, for the PD, the potential electoral costs of bipartisan dialogue, the effect of the heightened tension with $\mathrm{IdV}$ is then precisely to reduce the prospects of that dialogue even more.

Additional centre-left obstacles in the way of dialogue on constitutional reform probably exist as a result of the continuing political significance of the parties of the radical left. Of course, Veltroni had wanted to free himself of their encumbrance when, in the run-up to the 2008 election, he had refused a coalition agreement with them, forcing their supporters to make the choice between a principled vote and a 'voto utile'. But though he had been successful in eliminating the parties as a parliamentary force he had not eliminated them as more-or-less significant forces in the society at large. And having failed to attract sufficiently large numbers of their supporters to ensure that he won the election, it seemed reasonable to think that those he had won over might revert to their former choices - thus increasing the likelihood that he would be forced to terms with them in future electoral contests. In the aftermath of the vote, the arena in which this issue was thought to be of the most immediate significance was a number of important local authorities for which elections were due in the spring of 2009 and where the PD risked being ousted if it could not count on the support of the radical left (Pasquino, 2009: 241). These considerations too must have an important bearing on whether the two largest parties are able to engage in constitutional reform dialogue, if so, on what terms and with what outcomes.

For all these reasons, then, it is not surprising that, despite the initial hopes resting on the dramatic reduction in party-system fragmentation taking place in the parliamentary arena in 2008, we have not seen anything like the Bicameral Commission for Constitutional Reform that was established shortly after the centre left took office in 1996. And therefore, it remains unclear - to this author at least - that as conventionally understood, the term 'transition' is appropriate to the Italian context. While among the political elites there is some overlap of views on what a new constitutional settlement might look like, and while there is some commitment to the attempt to achieve it, the 
third vital ingredient - the existence of an actor of a group of actors with sufficient real power actually to make it a reality - is still not unambiguously present. It remains uncertain therefore, what it is that the Italian regime is supposedly in transition towards; and it remains the case that we will only be able to draw any conclusions about the applicability of the term after the event, that is, if and when a regime transition turns out in fact to have taken place. In the meantime, there do not appear to be any obvious theoretical benefits to be obtained from continuing to use the term. All of this throws a spotlight on the second issue: what does the outcome of the 2008 election imply for some broader notion of transition, that is, for the process of change in Italian politics more generally considered?

\section{The more general implications of 2008}

A seemingly widespread interpretation of 2008 is one that was expressed by Edmondo Berselli when he wrote (2008: 420) that 'the never-ending Italian transition' seemed, with the 2008 outcome, to have 'reached an initial milestone'. According to this view the election has brought to a culmination that process of change initiated with the birth of the Second Republic (increasingly used without the inverted commas) in the 1990s - such that for some, it is even legitimate to talk about the birth of a 'Third Republic' (see, for example, Giannini, 2008). In short, the idea is that 2008 seems to mark a watershed in terms of the performance of party system and political institutions so significant that, though the constitutional framework remains formally the same, the political system as a whole has in a real sense been transformed. What are the cases for and against this view?

On the one hand, we have: the dramatic reduction in party-system fragmentation; ${ }^{7}$ a strong executive (the small number of whose parties and the narrowness of the ideological space they cover free it from the blackmail to which the previous government was exposed), and a strong Prime Minister whose power was symbolised by the fact that he is said to have gone in to the customary post-election meeting with the President with the list of ministers already prepared, while the number of days separating the date of the election and the date the new government formally assumed office was the shortest in the history of the Republic: 24, for a post-war average of 46 .

On the other hand, at least two of the expectations about system performance created by these changes have so far gone unfulfilled. The first, stemming from the reduction in fragmentation, was that there would be the likely emergence in Parliament of rather more clear-cut governing and opposition roles, with more nearly 'Westminster'style patterns of interaction between them. As the country is a parliamentary democracy, politics since the war had of course always been based on the assumption that at any given moment certain parties were part of the governing coalition and the remainder part

\footnotetext{
${ }^{7}$ The actual number of groups in the Chamber of Deputies declined to six from the fourteen in existence at the end of the previous legislature, the effective number of groups (calculated, using the Laasko and Taagepera (1979) formula, as $\mathrm{N}=1 / \sum \mathrm{p}_{\mathrm{i}}{ }^{2}$, where $\mathrm{N}$ is the number of groups and $\mathrm{p}_{\mathrm{i}}$ is the fraction of seats of the ith group) from 6.04 to 3.11 .
} 
of the 'opposition'. However, in a context of high fragmentation, the legislative behaviour of the parliamentary groups had often belied such simple conceptualisations. Most proposals that made it on to the statute book did so thanks to ample majorities drawn from across the governing/opposition divide (Capano and Giuliani, 2001; Newell, 2006); and there was no formal recognition in Parliament's standing orders of an official opposition. Now we had not only a governing majority staffed by just two groups, but a similar simplification among the ranks of the non-governing parties as well and the consequent emergence of a 'shadow cabinet' drawn from the largest of these parties. Although the body has no formal, institutional recognition and excludes the Radicals and $\mathrm{IdV}$, it allows the work of each cabinet minister to be shadowed by a politician able, for the first time, to act as a spokesperson for the vast majority of those who are not part of the governing coalition. It was therefore reasonable to anticipate, all else equal, that the legislature would be marked by rather more straightforward patterns of interaction between more cohesive majority and minority coalitions.

Likewise, given the strength of the Government and Prime Minister, it was anticipated that there would be a significant improvement in improvement in the efficiency and effectiveness of policy-making at national level. What is the evidence?

The degree to which the period since the vote has actually seen the emergence of that more nearly Westminster-style of opposition initially expected - can be conveniently portrayed by asking the questions posed by Russo and Verzichelli (2009). That is: if we have seen the emergence of a 'shadow cabinet' capable of speaking for the vast majority of parliamentarians belonging to the opposition, to what extent are shadow ministers actually challenging their opponents in public? Second: To what extent are the opposition parties operating in alliance with each other?

Seven months after the start of the legislature five of the eighteen shadow cabinet ministers (not including Veltroni himself) who were parliamentarians had not made use of any of the procedures by which deputies and senators can ask questions of ministers. The remaining thirteen had presented 29 questions for written reply, 11 questions for oral reply, 14 questions for reply in committee and only 2 interpellations. Moreover, this activity, such as it was, was heavily concentrated: 22 of the questions for written reply, for example, had been asked just by shadow environment minister, Ermete Realacci. IdV was more active than the PD, its parliamentarians asking 18 percent of the total number of questions put by the three opposition groups though it numbered only 10.3 percent of the groups' parliamentarians - while PD parliamentarians, counting for 80.2 percent, put 70.0 percent of the questions.

A sample of 321 of the 2,220 questions put by the opposition parties confirmed that coordination between them was sporadic, only 27 questions (less than 10 percent) having been asked by parliamentarians of one group with the support of any of the other opposition groups. As Russo and Verzichelli (2009: 224-5) point out, 'Competition rather than cooperation seems to be the key to understanding relations among the three opposition parties in the initial months of the legislature'. If we ask why this is, then the 
obvious answer lies in the deep extra-parliamentary divisions among the opposition parties discussed above.

One of the ways in which we can test the validity of the expectation of greater efficiency and effectiveness of policy making is in terms of the success rate of government bills, that is, in terms of the proportion of government-sponsored legislative proposals which, once introduced, then actually make it to the statute book. Of course the measure is vulnerable to the law of anticipated reactions and can tell us little about the efficiency and effectiveness of policy in substantive terms. However, with these caveats, the measure ought to be quite revealing. Primary responsibility for initiating public policy lies with national governments. Therefore, their ability to 'get their way' would seem to be a necessary pre-requisite for efficiency and effectiveness in the policy-making process as a whole.

Table 2 shows that the current government's success rate does not stand out especially as compared to success rates in earlier legislatures: to date it has secured approval for 68.6 percent of its proposals for a post-war average of 73.7 percent. Arguably, the comparison is unfair: at any point in the initial stages of a legislature a proportion of government bills destined to be approved, will still be under consideration. But the picture changes little when we compare the period since the start of the current legislature with the corresponding period following the start of the preceding legislature: during that period, the success rate was 64.3 percent, even though the government in office at that time was litigious and its parliamentary support base, in the Senate at least, fragile.

Whatever the reality, perceptions of an improvement in the quality of government policy-making appear to have persisted. When in August 2008, the American magazine, Newsweek, published an article praising Berlusconi for having, as it put it, 'brought order to chaotic Italy' (Barigazzi, 2008) it reflected a public mood whose endurance is captured by the data shown in Figure 1. While at the start of Berlusconi's mandate 53 percent had 'a lot' or 'quite a lot' of confidence in him as Prime Minister, eight months on the proportion was 55 percent. The proportion expressing 'a lot' or 'quite a lot' of confidence in the Government as a whole has remained more or less stable at around a half. Now compare these with the proportions expressing confidence in Prodi and his government over the first eight months of their mandates. From Figure 2 we can see that though they start out from proportions actually higher than those marking the start of the current prime minister and government, the proportions then fall away rapidly to levels much lower than those enjoyed by the current incumbents.

To my mind, there is a very simple explanation for the difference. It is that the 2008 election marked the advent of a government and prime minister which, if they still have much to do to demonstrate improved actual performance (given the short time they have been in office) they have, through their approvals ratings, confirmed that, as incumbents much stronger than their predecessors, they are much better placed than the latter to create the impression of good governing performance. This is because, precisely due to the relative compactness of the governing majority, they are much better placed to 
engage in that permanent campaigning - using support mobilisation as a key resource for governing, while using governing as an instrument to build and sustain support - that is essential for survival in mediated democracies.

Prodi was handicapped in this respect because, having to manage a coalition composed of large numbers of parties each driven by the 2005 electoral law ${ }^{8}$ to keep salient its own distinctiveness, he was never able effectively to use communication as a tool in the battle to control the political agenda. What happened, therefore, was that litigiousness became equated - quite erroneously - with policy-making ineffectiveness with the result that the Government found itself caught in a vicious circle. That is, in terms of policy, the Government actually had quite a creditable record - as a number of authors (e.g. Paolucci and Newell, 2008; Walston, 2008; Capriati, 2009; Fois, 2009) have shown; but it was able to do little to counteract the tendency of the media, in their constant search for the newsworthy, to highlight feuds and divisions and so frame the government as 'catastrophic' (Roncarolo and Belluati, 2008). In doing so, willingly or otherwise, the media necessarily gave credence to the opposition's portrayal of the Government - so fuelling the downward trajectory in its poll ratings, shortly after it took office. And the more the Government was portrayed as litigious and ineffective, the more litigious and unstable it actually became as the parties, first, argued about how to retrieve the position and then came to be driven by a logic of si salvi chi può. It seems possible, then, that 2008 may come misleadingly to be seen as marking the start of a significant improvement in government performance, because impressions of that performance get compared with misleading accounts of the past.

\section{Conclusion}

Whether the outcome of the 2008 election will prove to be the catalyst that gives Italy the long hoped-for constitutional overhaul remains highly uncertain. And since the existence of a process of transition can necessarily be conclusively established only after the event, this suggests that as conventionally understood - that is, as formal change in the nature of the regime - the term is now best abandoned in analyses of Italian politics.

What seems somewhat more probable, all else equal, is that 2008 will come to be perceived as the culmination of a process of transition understood in the broader sense of transformation in the performance and mode of functioning of a political system. Such a

\footnotetext{
8 As its authors had intended: by stipulating that all votes - even those of parties remaining below the (low) thresholds for the assignment to them of seats - count for the purposes of assignment to the coalition of the premium, the 2005 electoral law had removed almost all the political costs that might otherwise have been associated with voting for a minor formation belonging to one of the two major coalitions (Floridia, 2008). Vote-seeking parties, if they are to maximize their support, are obliged to compete for media exposure and communication space...[But] attracting media attention requires provocation, division and confrontation' (Paolucci and Newell, 2008: 289). It was no wonder, then, that the Prodi government found it so difficult to control the flow of information in its communications with citizens and thus keep control of the political agenda. Nor is it any wonder that it ended up with a reputation for ineffectiveness and became so bitterly unpopular. The Berlusconi government, with its coalition of two, and a cabinet in which the Prime Minister's own party has an absolute majority, has none of these difficulties.
} 
view is likely to be significantly influenced by perceptions of how the performance of the current government compares with that of the government it replaced. There is a significant risk that such perceptions will be inaccurate. As the fate of the last government demonstrates, perceptions, however inaccurate, often turn out to have real, and sometimes unfortunate, consequences. For this reason it is very much to be hoped that the sense of responsibility of students of Italian politics will lead them, in the coming months and years to assess that country's political developments, and claims made about them, with an especially critical eye.

\section{References}

Albertazzi, D., McDonnell, D. and Newell, J.L. (2007) 'Di lotta e di governo: The Lega Nord and Rifondazione Comunista in coalition', paper presented to the panel, 'Outsider parties in Western Europe: the opposition in government? I', at the 57th Annual Conference of the UK Political Studies Association, 11 -13 April, University of Bath.

Barigazzi, J, (2008), 'Miracle in 100 days. How Berlusconi brought order to chaotic Italy and what comes next', Newsweek, 9 August, http://www.newsweek.com/id/151669 loutput/print

Berselli, E. (2008) 'Partito democratico o partito ipotetico', il Mulino, 437: 420-431.

Biorcio, R. and Bordignon, F. (2008), 'Lega e Idv, i “duri” mietono consensi', la Repuublica, 6 July, p.7.

Budge, I. and Farlie, D. (1983) Explaining and Predicting Elections: Issue Effects and Party strategies in Twenty-Three Democracies, London: Allen and Unwin.

Budge, I., Robertson, D. and Hearl, D. (1987) (eds.) Ideology, Strategy and Party Change: Spatial Analysis of Post War Election Programmes in 19 Democracies, Cambridge: Cambridge University Press.

Bull, M.J. (2007) 'La grande riforma del centre-destra alla prova del referendum', pp. 123-145 in J-L Briquet and A. Mastropaolo (eds), Politica in Italia I fatti dell'anno e le interpretazioni, Bologna: il Mulino.

Bull, M.J. and Newell, J.L. (2009) 'Still the Anomalous Democracy? Politics and Institutions in Italy' Government and Opposition 44(1): 42-67.

Berlusconi, S. (2000) L'Italia che ho in mente, Milan: Mondadori.

Campus, D. (2009) 'Campaign themes and issues', pp.137-149 in J. L. Newell (ed.), The Italian General Election of 2008, London and Basingstoke: Palgrave. 
Capano, G. and Giuliani, M. (2001) 'Governing Without Suviving? An Italian paradox: law-making in Italy 1987-2001', Journal of Legislative Studies 4: 13-36.

Capano, G. and Giuliani M. (2003) 'The Italian Parliament: In Search of a New Role?', Journal of Legislative Studies 9(2): 8-34.

Capriati, M. (2009) 'The economic context', pp. in J. L. Newell (ed.), The Italian General Election of 2008, London and Basingstoke: Palgrave.

Chiaramonte, A. (2009) 'Italian voters: Berlusconi's victory and the 'new' Italian party system', pp.193-210 in J. L. Newell (ed.), The Italian General Election of 2008, London and Basingstoke: Palgrave.

Di Caro, P. (2008), 'Casini: Di Pietro polizza sulla vita del premier, il Pd lo scarichi', Corriere della Sera, 30 June, p.5.

Diamanti, Ilvo (2008), 'Il “non luogo dei democratici” la Repubblica, 21 December.

Favretto, I. (2009) 'The parties of the centre left', pp.85-101 in J. L. Newell (ed.), The Italian General Election of 2008, London and Basingstoke: Palgrave.

Flores d'Arcais, P. (2008), 'Una lista civica per le europee', MicroMega, no. 5, pp.3-9.

Floridia, A. (2008) 'Gulliver Unbound. Possible Electoral Reforms and the 2008 Italian Election: Toward an end to 'Fragmented Bipolarity?', Modern Italy 13(3): 317-332.

Fois, G.A. (2009) 'The EU and international contexts', pp.62-81 in J. L. Newell (ed.), The Italian General Election of 2008, London and Basingstoke: Palgrave.

Giannini, M. (2008), 'Terza repubblica, stesso cavaliere', la Repubblica, 15 April, http://www.repubblica.it/2008/04/sezioni/politica/elezioni-2008-uno/giannini-voto /giannini-voto.html

Laasko, M. and Taagepera, R. (1979) "Effective” Number of Parties: A Measure with Application to West Europe', Comparative Political Studies 12(1): 3-27.

Mannheimer, R. (2008), 'Il Pd delude il 40\% dei suoi: troppo remissivo' , Corriere della Sera, 15 June, p.11.

MEF [Ministero dell'Economia e delle Finanze] (2008) Relazione Unificata sull'Economia e la Finanza Pubblica, Rome, 20 March.

Montanari, A (2008) 'Riforme, scontro tra Berlusconi e Pd Veltroni: No aldialogo se c'è l'immunità', la Repubblica, 19 July, p.7. 
Newell, J.L. (2006) 'Characterising the Italian Parliament: legislative change in longitudinal perspective', Journal of Legislative Studies 12(3-3): 386-403.

Paolucci, C. and Newell, J.L. (2008) 'The Prodi government of 2006 and 2007', Modern Italy 13(3): 283-291.

Pasquino, G. (2000) La transizione a parole, Bologna: il Mulino.

Pasquino, G. (2009) 'The formation of the fourth Berlusconi government', pp.282-242 in J. L. Newell (ed.), The Italian General Election of 2008, London and Basingstoke: Palgrave.

Ricolfi, L. (2008), 'Perché le sinistre hanno perso', pp.49-59 in R. Mannheimer and P. Natale (eds), Senza più sinistra, Milan: il Sole 24 Ore.

Roncarolo, F. and Belluati, M. (2008) 'Surfing and trying to keep afloat. The political communication process in a highly fragmented coalition led by a 'Great Mediator', Modern Italy 13(3): 333-348.

Russo, F. and Verzichelli, L. (2009), 'A different legislature? The parliamentary scene following the 2008 elections', pp.211-227 in J. L. Newell (ed.), The Italian General Election of 2008, London and Basingstoke: Palgrave.

Sartori, G. (1976), Parties and Party-systems: A Framework for Analysis, Cambridge: Cambridge University Press.

Tsebellis, G. (2002) Veto Players: How Political Institutions Work, Princeton N.J.: Princeton University Press-Russell Sage Foundation.

Urbani, G. (2009), Interview with Aldo Cazzullo, 'Urbani: il progretto del «nuovo» Pdl? La debolezza delPd ci contaggia', Corriere della Sera, 15 January, p.6.

Vassallo, S. (2007), 'Government under Berlusconi: The Functioning of Core Institutions in Italy', West European Politics 30(4), pp. 692-710.

Veltroni, W. (2007) La Nuova Stagione, Milan: Rizzoli.

Walston, J. (2008) 'La politica estera : il difficile perseguimento di un ruolo influente', pp. 151-171 in M. Donovan and P. Onofri (eds), Politica in Italia : I fatti dell'anno e le interpretazioni, 2008 edition, Bologna : il Mulino. 
Table 1 Composition of the parliamentary groups, Chamber of Deputies and Senate, 2008

\begin{tabular}{|l|r|r|r|r|}
\hline & \multicolumn{2}{|c|}{ Chamber } & \multicolumn{2}{|c|}{ Senate } \\
\hline Group & No. & \multicolumn{1}{l|}{$\%$} & No. & $\%$ \\
\hline Italia dei Valori & 28 & 4.4 & 14 & 4.3 \\
\hline Lega Nord Padania & 60 & 9.5 & 26 & 8.1 \\
\hline Partito Democratico & 218 & 34.6 & 119 & 37.0 \\
\hline Popolo della Libertà & 273 & 43.3 & 146 & 45.3 \\
\hline UDC & 35 & 5.6 & 11 & 3.4 \\
\hline Groupo Misto & 16 & 2.5 & 6 & 1.9 \\
\hline Total & 630 & 99.9 & 322 & 100.0 \\
\hline
\end{tabular}

Table 2 Success rate of government bills

\begin{tabular}{|l|l|r|r|r|}
\hline Legislature & & $\begin{array}{l}\text { Presented } \\
\text { chamber }\end{array}$ & & \\
& I the & Number approved & $\begin{array}{l}\text { Proportion } \\
\text { approved (as \% of } \\
\text { number presented) }\end{array}$ \\
\hline $1948-1953$ & I & 2,199 & 1,996 & 92.8 \\
\hline $1953-1958$ & II & 1,564 & 1,439 & 92.0 \\
\hline $1958-1963$ & III & 1,484 & 1,340 & 90.3 \\
\hline $1963-1968$ & IV & 1,442 & 1,259 & 87.3 \\
\hline $1968-1972$ & V & 831 & 663 & 79.8 \\
\hline $1972-1976$ & VI & 1,133 & 941 & 83.1 \\
\hline $1976-1979$ & VII & 831 & 644 & 77.5 \\
\hline $1979-1983$ & VIII & 1,242 & 861 & 69.3 \\
\hline $1983-1987$ & IX & 1,175 & 769 & 65.4 \\
\hline $1987-1992$ & X & 1,369 & 922 & 67.3 \\
\hline $1992-1994$ & XI & 653 & 292 & 44.7 \\
\hline $1994-1996$ & XII & 819 & 318 & 38.8 \\
\hline $1996-2001$ & XIII & 1,222 & 695 & 56.9 \\
\hline $2001-2006$ & XIV & 1,471 & 1,284 & 87.2 \\
\hline $2006-2008$ & XV & 423 & 331 & 78.2 \\
\hline $2008-$ & XVI & 175 & 120 & 68.6 \\
\hline
\end{tabular}

* Situation as at 19 February 2009.

Source: legislatures I to XII: della Sala (1998, table 4.4a); legislatures XIII to XVI, own elaboration based on data available at www.senato.it 


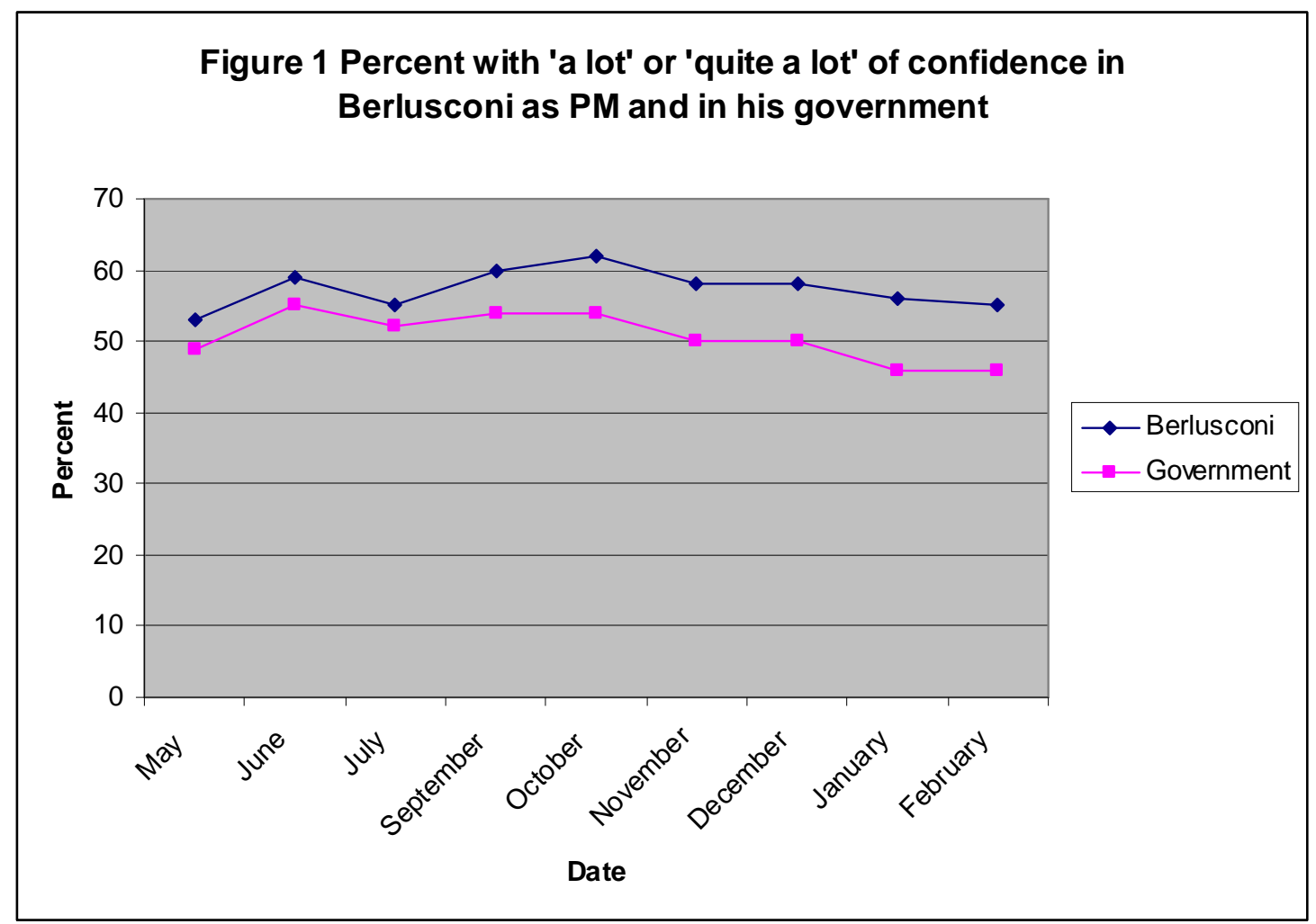

Source: IPR Marketing, www.sondaggipoliticoelettorali

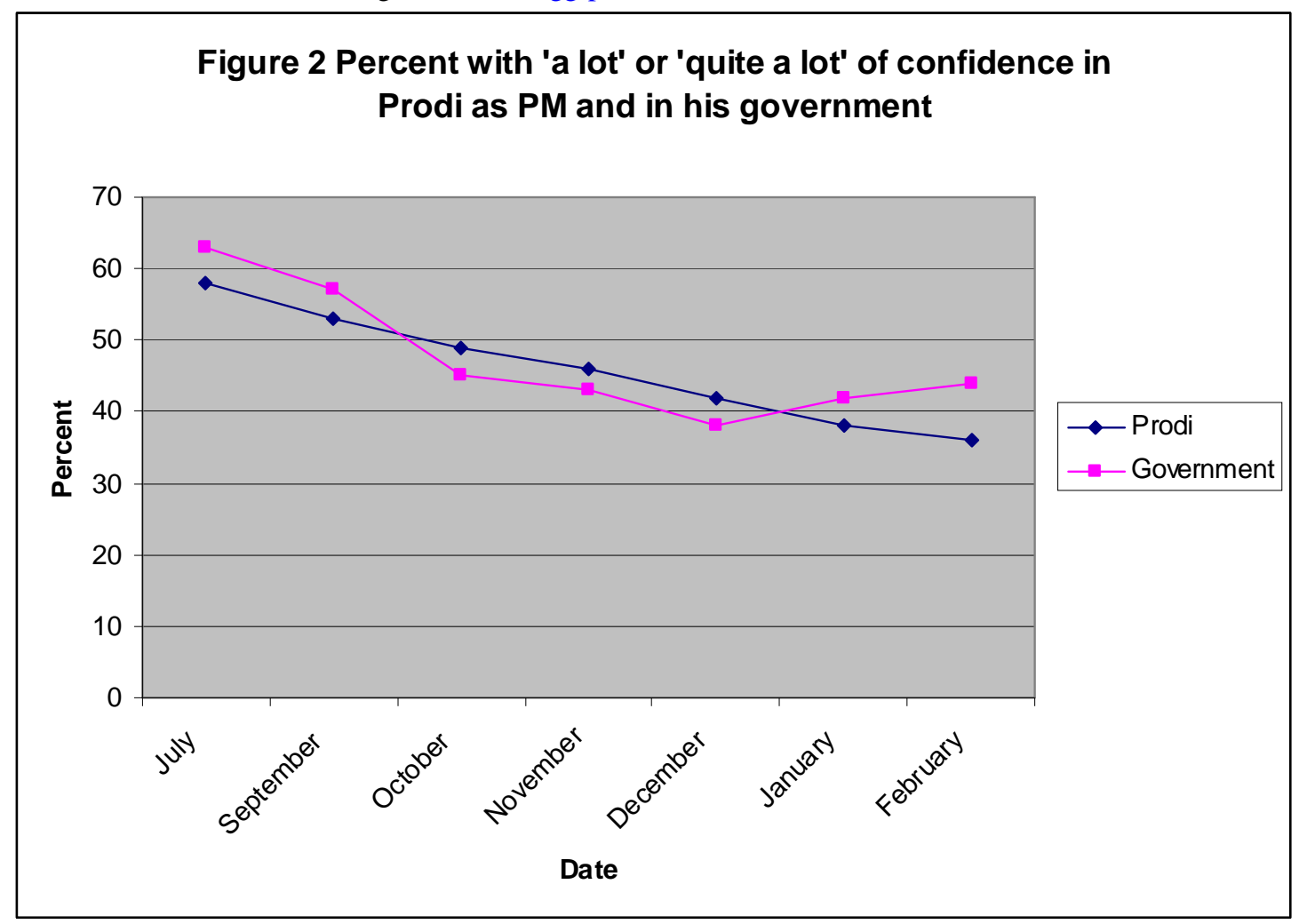

Source: IPR Marketing, www.sondaggipoliticoelettorali 